\title{
Labour Market Policies and Social Investment in Montenegro: Attaining European Standards and Practice?
}

\author{
BRANKO BOŠKOVIĆ* \\ Humanistic Studies \\ University of Donja Gorica \\ Donja Gorica, Podgorica, Montenegro
}

\author{
Review paper
$.01: 658(497.16)$ \\ UDK: $364.01: 658(497.16)$ \\ Received: January 2019
}

The paper analyses the developments of the labour market policies in Montenegro from the perspective of social investment. Montenegro is a candidate country for the European Union membership and there is a need of harmonisation of normative framework. Social investment is gaining considerable attention of EU policy makers and is positioned highly on the social policy agenda. Consequently, the paper examines whether Montenegrin labour market performs in the similar fashion as in the EU. The aim of the research is to show whether Montenegrin labour market will be ready for the accession, both normatively and in practice. Active labour market policies are in the focus of the paper, as they are one of the most representative social investment measures in this policy area. There is also an analysis of two specific policies: so called "mothers'allowances" and the "apprentice programme". This analysis shows that Montenegro has a good starting point in terms of the legal framework it has enacted, but in practice, social investment is not present.

Key words: Montenegro, European Union, social policy, active labour market policies, social investment.

\section{INTRODUCTION}

The economic crisis gave a boost to an already looming literature in the area of social policy. Questioning approaches and looking into specific policies of the welfare state in Europe made research into the subject even more pronounced. At the same time, the most recent member states implemented the necessary reforms, with one chapter of the accession negotiations comprising social policy and employment. Montenegro is in the focus of this paper as it strives to adopt the acquis communau- taire and to reform its legal framework in accordance with the EU standards.

Employment and social policy have not been in focus of the research in Montenegro and scientific conclusions are missing. An analysis of social investment is missing as well, so this paper is a contribution to expansion of the debate beyond merely the official documents. Moreover, it has a twofold aim: to see if there is social investment in social policy in Montenegro and to see if it has any influence on the labour market policies. It is crucial to see if Montenegrin

\footnotetext{
* Branko Bošković, Humanističke studije, Univerzitet Donja Gorica / Humanistic Studies, University of Donja Gorica, Oktoih 1, 81000 Podgorica Crna Gora / Montenegro, branko.boskovic@udg.edu.me
} 
citizens will be ready for the EU membership, but equally important is to see the institutional framework. In other words, comparing Montenegrin social investment "situation" with the EU member states will show what further policies need to be adopted related to the major aspects of this approach. The paper uses a twofold approach to this question. Firstly, the overall perspective deals with social investment while, secondly, it focuses on specific labour market policies, with special attention paid to activating policies.

The paper presents a research on Montenegrin labour market, examining whether social investment is present as a paradigm in labour market policies, but also comparing Montenegro with the European Union member states. It is divided into five major sections. The first part discusses the strategic framework which is used for assessing Montenegrin labour market. The second outlines the framework of the research and the third is a theoretical section on social investment. The fourth part discusses how active labour market policies function. The fifth section is the most comprehensive one and it presents the analysis of the specific policy measures chosen in this paper.

\section{MONTENEGRO AND THE EUROPEAN UNION: LABOUR MARKET REFORMS AND EXPECTATIONS}

Eastern and Central European countries have witnessed the difficulty of implementing reforms and it is the case with the prospective member states as well, Montenegro being one of them. Major strategic documents point to the European 'direction' of Montenegrin legal framework, but the paper aims at showing if there is a specific policy outreach in Montenegrin social policy. Social investment is a contested paradigm, but current social trends, which are being discussed here, point to a need to further develop and strengthen human capital.
Montenegro has been a candidate country for the European Union membership since 2012. The Chapter 19 of the membership negotiations, on social policy and employment, was opened in 2016 and it is important to see how it is dealt with by the country. Social investment is chosen because it has been placed high on the EU's social policy agenda. For this paper, two major sources are used, the ones related to the European Union and the others related to Montenegrin labour market reforms. It is necessary to have a focal point on social investment from which the labour market can be assessed with precise and explicit findings. The major documents adopted by the European Union after the 2008 crisis stress the relevance of labour market functionality, but also the social investment perspective. Three are especially relevant for this research: Europe 2020, An Agenda for New Skills and Jobs and Social Investment Package. The details of each are not discussed here, but the major outcomes stressed are: increasing employment rates, creating skilled workforce and developing knowledge, improving job quality, addressing poverty, ageing population, targeting of social policies, innovation, investment and life cycle perspective (European Commission, 2010a.; European Commission, 2010b.; European Commission, 2013a). Additional rationale can be found in other documents as well (European Commission, 2013b; 2017).

Montenegro has adopted a substantial part of the acquis in this policy area as presented by the official institutions: the Action Plan for the Chapter 19 of Negotiations for the EU Membership and strategic documents of the Montenegrin Government address the issue, stressing the need for further reforms in the labour market policies, especially activating measures (Ministry of Work and Social Welfare, 2015a; 2015b; 2015c). The Progress Report of the European Commission for 2016 stated the need of further improvement of the allocation of 
active labour market policies and the legislation which discouraged women's labour market participation (European Commission, 2016). The Report for 2018 stressed the need of further improvements in the policy area (European Commission, 2018). Montenegro has been labelled as a jobless growth country (Ministry of Work and Social Welfare, 2015b) and active labour market policies may offer a good way for individuals to reskill or retrain.

\section{The framework of the research}

The study aims at showing whether social investment is recognised in Montenegrin labour market policies and whether specific policies result in outcomes similar to the EU levels. It will be done by looking at assumptions, dimensions and instruments of this policy approach in official documents, but also in the actual data. More specifically, it will look at how ALMPs are regulated and implemented and what their results are. The main hypothesis of the paper is: social investment policies are present in the Montenegrin social policy framework, especially in the labour market policies.

ALMPs will be assessed by type and availability and by Bonoli's categorisation (Bonoli, 2012) together with the European Commission's statistical unit (European Commission, 2006). These categorisations clearly delineate between different types of measures and are functional for assessing an investment-oriented approach. Effects of ALMPs will be assessed in accordance with the indicators used in the national reports on social investment in the EU (Bouget et al., 2015).

Montenegro does not participate in labour market policies framework, used by the European Commission and consequently, Montenegrin practice cannot be compared with the EU member states in the same vein because it needs adaptation, as will be seen in the rest of the paper. The following indicators will be used in the paper: specific policy measures of ALMPs used; the number of participants at ALMP in each of the policy measures; unemployment levels of the total active population, especially for women and youth; eligibility criteria for unemployment benefits; the number of long-term unemployed; expenditure on ALMPs as per cent of the budget. Youth unemployment is seen by the EU as one of the greatest hurdles to improve the welfare of our societies, so there will be an assessment of the apprentice programme. It is highly relevant for this paper due to its investing character, but also due to its possible contributions to increasing employment. Also, strategic documents prioritise its potential to improve employment opportunities for young persons, especially because of the lack of systemic cooperation between education system and employers (Ministry of Work and Social Welfare, 2015b; 2015c).

\section{WHY SOCIAL INVESTMENT IS IMPORTANT FOR SOCIAL POLICY DEVELOPMENT}

Social investment is recognised as the paradigm or approach that aims at increasing human capital and the ability of individuals to have quality jobs. The notion refers to interventions that help individuals improve their life chances, especially by combining education and labour market (Bonoli, 2009). The necessity of the reform was accentuated by: moderate growth levels with increasing fiscal pressures, population ageing and declining fertility rates, technological changes, economic internationalisation, rising number of women in employment, changing family structures and gender roles and longer education (Bonoli, 2007; Hemerijck, 2013). Social policy is here seen as a precondition for economic growth and the state has a key role in developing human capital, providing services and helping avoid human capital depletion (Morel et al., 2012). 
Due to the novelty of these ideas and policies, there is still no agreement on the exact labelling of social investment: emerging paradigm, approach, perspective or paradigm or even other (Jenson \& Saint-Martin, 2006; Jenson, 2009; Hemerijck 2013; Morel et al., 2012). The major innovation of social investment is a turn towards preparation and fostering prevention (Jenson, 2012). Sources of innovation are internal and external. Internal ones are: ageing population, declining fertility, changing family forms and moving away from the male-breadwinner model, and external ones are: globalization, moving towards service and knowledge based economy, rising unemployment, unexpected economic shocks (Clasen \& Clegg, 2006; Esping-Andersen et al., 2002; Hemerijck, 2013), to name just a few. Pierson (2011) states that we live in the time of permanent austerity and it is one the major factors shaping social policy today.

In this context social investment can be seen as a two-fold alternative: first, as a response to neoliberal retrenchment of social spending and, second, as a way of overcoming disappointing trends in terms of poverty and social exclusion (Nolan, 2013; Morel et al., 2012; Hemerijck \& Vandenbroucke, 2012). Vandenbroucke et al. state a dual ambition of social investment: modernising welfare state and ensuring the sustainability of the welfare state, and upholding a knowledge-based economy (Vandenbroucke, Hemerijck \& Palier, 2011). On the other hand, the crisis only confirmed the need for a more all-encompassing view that strengthens relationship between qualifications and possibilities and collective welfare (Bošković, 2015).

Changing patterns of work require different policy responses, and just as Polanyi (2003) stated, labour market functions in accordance with political intervention. The golden age of the welfare state and a Keynesian demand economy have been sur- passed and reorientation was made to the supply side. Consequently, long-term unemployment and skills shortages which were marginal problems then now became much more prevalent (Clasen \& Clegg, 2006). The same authors state three novel dimensions of the post-industrial labour market: more frequent transitions, heavier dependence on individual skills and experience and increasing flexibility which often results in a downward adjustment of workers' wages.

\section{Active labour market policies: social investment in practice}

Having a quality job and not just any job should be the major outcome of investment policies, but participation rates can vary independent of the individuals, e.g. due to recession, economic downturns, global negative trends (Martin, 2015). In the similar vein, labour market policies may be dispersed in different ways, ranging from passive to active policies. Some cash benefits of indirect support can be labelled as investment oriented: sick leaves, unemployment benefits or parental leaves are just some of the examples. When they were first introduced, the major aim of activating policies was narrowly defined as increasing public resources spent opposed to passive policies, e.g. unemployment insurance (Martin, 2015). Historically, ALMPs were not always designed to increase labour market participation, but sometimes just to stop depletion of human capital (Bonoli, 2012).

OECD does not define activation policies but points to their aims: bringing more people into labour force, counteracting potentially negative effects of unemployment and related benefits, enforcing conditionality on active search for a job, improving employability, managing employment services and promoting and assisting return to work (OECD, 2013). Activating policies especially aim at women and youth. These categories of society are especially vulner- 
able, among other things because of their lower social capital and possibilities of easier dropping out of the labour market, (e.g. Esping-Andresen et al., 2002). Decreased human capital, as well as frequently low potential and low paid jobs contributed to their vulnerability from economic shocks. Consequently, activating policies should have the potential to reduce gender and age differences. However, there is evidence that this is not the case (e.g. Caliendo \& Schmidl, 2016; Martin, 2015). Returning to any work may not mean a satisfying long-term job and it is a question if active labour market policies can play a role here, especially for the long-term unemployed. Despite the cautionary principles stated here, these policies have the potential for reducing all of the negative effects of internal and external labour market alterations.

\section{ACTIVE LABOUR MARKET POLICIES IN MONTENEGRO: EXPECTATIONS, AVAILABILITY, EFFECTIVENESS}

As other societies, Montenegro is facing similar challenges and the Government recognised the need of increasing employment rates, especially for youth, addressing the problem of the long-term unemployed, as well as challenges of demographic trends (Ministry of Work and Social Welfare, 2015b; 2015c: Zavod za statistiku, 2014). The same documents prioritise active labour market policies. Montenegrin law on employment and fulfilment of unemployment insurance rights (2016) (hereinafter: LEFU) defines active labour market policies as plans, programmes and measures aiming at increasing of the employment and reduction of unemployment. It is a broad definition,

Table 1

Active labour market policies categorisation

\begin{tabular}{|c|c|c|c|c|c|}
\hline & \multicolumn{3}{|c|}{ Investment in human capital } \\
\hline & 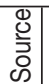 & 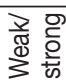 & None & Weak & Strong \\
\hline \multirow{8}{*}{ 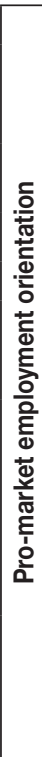 } & \multirow{5}{*}{ 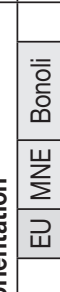 } & \multirow{4}{*}{ 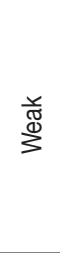 } & (passive benefits) & Occupation & (basic education) \\
\hline & & & & $\begin{array}{l}\text { Job creation schemes in the public } \\
\text { sector, Non-employment related } \\
\text { training programmes }\end{array}$ & \\
\hline & & & & Public jobs & \\
\hline & & & & Job rotation, Job sharing & \\
\hline & & \multirow{4}{*}{$\begin{array}{l}\text { O } \\
\text { D } \\
\text { 离 }\end{array}$} & Incentive reinforcement & Employment assistance & Upskilling \\
\hline & \multirow{2}{*}{ 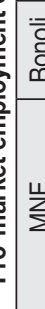 } & & $\begin{array}{l}\text { Tax credits, In-work benefits, } \\
\text { Time limits on recipiency, Benefit } \\
\text { reductions, Benefit conditionality }\end{array}$ & $\begin{array}{l}\text { Placement services, Job subsidies, } \\
\text { Counselling, Job search programmes }\end{array}$ & Job-related vocational training \\
\hline & & & Time limits, Benefit conditionality & $\begin{array}{l}\text { Informing of possibilities and conditions } \\
\text { for employment, Mediation, Individual } \\
\text { plans, Professional orientation, } \\
\text { Qualification for the individual } \\
\text { work, Support for self-employment, } \\
\text { Employment subventions, Scholarships }\end{array}$ & $\begin{array}{l}\text { Education and qualification } \\
\text { of adults, Professional } \\
\text { rehabilitation of employable } \\
\text { persons, Qualification for work } \\
\text { at the employer }\end{array}$ \\
\hline & 岂 & & $\begin{array}{l}\text { Recruitment incentives, } \\
\text { Employment maintenance } \\
\text { incentives, Time limits, Benefit } \\
\text { conditionality }\end{array}$ & Supported employment, Rehabilitation & $\begin{array}{l}\text { Institutional training, } \\
\text { Workplace training, Alternate } \\
\text { training, Special support for } \\
\text { apprenticeship }\end{array}$ \\
\hline
\end{tabular}

Source: Bonoli, 2012; European Commission 2006; LEFU. 
however, the aim of policies should be to increase employment rates. Table 1 presents Bonoli's categorisation, ALMPs in Montenegro and division used by the European Commission's Guidelines for labour market policy statistics (European Commission, 2006).

Bonoli defines incentive reinforcements as measures which aim is to strengthen work incentives for benefit recipients; employment assistance refers to measures which aim at obstacles to labour market participation; occupation refers to measures which aim at prevention of human capital depletion and keeping people busy; upskilling refers to providing training for jobless, with the aim to improve their skills and increase their ability to participate in the labour market (Bonoli, 2012, 184-185). Table 2 provides the definitions of ALMPs in Montenegro.
Despite the definition of the active labour market policies, it can be seen that not all of the measures have a direct impact on increasing employment. However, measures aiming at employment assistance are the most represented ones. In accordance with previous conclusions, it is upskilling that most strongly refers to social investment for its human capital orientation, but employment assistance helps re-entering labour market. It can be seen that the majority of policy measures in Montenegro belong to employment assistance and upskilling, even more than in the EU. Consequently, in the sense of the availability of specific measures, social investment paradigm is present in active labour market policies in Montenegro. But, neither effective legal framework nor high social care expendi-

Table 2

Definition of ALMPs in Montenegro

\begin{tabular}{|c|c|}
\hline ALMP & Definition \\
\hline Public jobs & Employment of persons with low employability opportunities, on a specific period \\
\hline $\begin{array}{l}\text { Informing of possibilities and } \\
\text { conditions for employment }\end{array}$ & Providing information to the unemployed concerning opportunities for employment \\
\hline Mediation & Activities of connecting unemployed and employers with the aim of finding a job \\
\hline Individual plan & $\begin{array}{l}\text { Plan of activities agreed between unemployed and the prospective employers so } \\
\text { they become more engaged in ALMP, with no obligation to provide them with a job; } \\
\text { plans can be changed when it is necessary. }\end{array}$ \\
\hline Professional orientation & $\begin{array}{l}\text { Providing help to individuals, to enable them to improve their career prospects and } \\
\text { be more aware of the current needs of the labour market }\end{array}$ \\
\hline $\begin{array}{l}\text { Qualification for the individual } \\
\text { work }\end{array}$ & $\begin{array}{l}\text { Activities which aim at enabling unemployed to improve their skills for the acquired } \\
\text { level of education so they are able to work independently }\end{array}$ \\
\hline Support for self-employment & $\begin{array}{l}\text { Financial and specialist assistance for the unemployed who wish to start their } \\
\text { own business }\end{array}$ \\
\hline Employment subventions & Financial assistance for employers who provide job the unemployed \\
\hline Scholarships & Financial assistance to the unemployed according to the needs of the labour market \\
\hline $\begin{array}{l}\text { Education and qualification of } \\
\text { adults }\end{array}$ & $\begin{array}{l}\text { Activities which enable the unemployed to acquire a qualification for the first job, } \\
\text { to improve his knowledge and the level of education, earn new qualification and } \\
\text { gain new skills }\end{array}$ \\
\hline $\begin{array}{l}\text { Professional rehabilitation of } \\
\text { employable persons }\end{array}$ & $\begin{array}{l}\text { Enabling individuals with lower opportunities for employment to work, keep their } \\
\text { position or improve their current position }\end{array}$ \\
\hline $\begin{array}{l}\text { Qualification for the work at the } \\
\text { employer }\end{array}$ & $\begin{array}{l}\text { Improving skills and knowledge of the unemployed with the aim of employment at } \\
\text { the predefined employer }\end{array}$ \\
\hline
\end{tabular}

Source: LEFU. 
tures are a guarantee of positive outcomes. As already mentioned, social investment literature stresses coordination as one of the key stones in successful policy outcomes (Hemerijck, 2017).

Unemployment benefits are modest in Montenegro, compared to the EU member states, based on benefit conditionality and time limits criteria (Esser et al., 2013; Maquet et al., 2016; Venn, 2012). Montenegro does not have a classic unemployment insurance scheme, but rather it is an unemployment cash benefit which represents the most common means of protection and it includes medical and pension insurance. The unemployed are entitled to the unemployment benefit, if they worked for at least 12 months in the last 18 months and it is available from the first day of the application. The benefit can be received from 3 to 12 months, depending on the previous employment record, with more supportive treatment of persons with 35 or more years of employment (LEFU). The benefit rate is 40 per cent of the minimum wage. However, conditionality is also favourable in comparison with the EU member states (e.g. Bouget et al., 2015).

Compared to the EU member states, benefit conditionality is fairly generous although it is not a flat rate. In terms of social investment, there is barely any support here for individuals to focus on their human capital enrichment or look for a job they may find suitable. This kind of support does not encourage considerations on the long run, but rather pushes the unemployed to take any job due to lack of basic means for living. The replacement rate has increased by $4 \%$ since 2011 , up to $15.05 \%$ in 2018 , but it is still very modest and discouraging in the long run.
Table 3

Coverage rate of beneficiaries and the net replacement rates as the \% of the monthly average net earnings

\begin{tabular}{lcc}
\hline Year & $\begin{array}{c}\text { Coverage rate of } \\
\text { beneficiaries }\end{array}$ & $\begin{array}{c}\text { Net replacement } \\
\text { rate }\end{array}$ \\
\hline 2011 & 37.96 & 11.98 \\
\hline 2012 & 31.60 & 11.99 \\
\hline 2013 & 28.07 & 16.11 \\
\hline 2014 & 24.57 & 16.18 \\
\hline 2015 & 16.30 & 16.08 \\
\hline 2016 & 14.93 & 15.47 \\
\hline 2017 & 16.54 & 15.08 \\
\hline 2018 & 25.43 & 15.05 \\
\hline
\end{tabular}

Source: Employment Agency of Montenegro 2011 - 2018; Katnić, 2017.

Participation rates for unemployment benefit are also among the lower ones compared to the EU member states. There is a steady decrease in the number of beneficiaries, but the number of the unemployed has significantly increased as well, with the exception of 2018 which saw an increased number of beneficiaries, but well below 2013 or earlier years. The overall conclusion is that increased unemployment rates lead to increased numbers of people who did not receive the unemployment benefit. Compared to the EU member states, the Montenegrin position has declined significantly behind the ones with higher participation rates.

The Table 4 shows the number of beneficiaries in Montenegro. First, the number of participants in ALMPs significantly increased in 2017, with the similar trend in 2018 and with a modest budget increase. Second, the number of participants in activating measures varies and not all of the unemployed participate. Third, the table shows a very low number of participants in upskilling and therefore social investment is not present in the actual practice of ALMPs in Montenegro. Even more, the number of participants in these measures 
Table 4

Number of participants for each measure in Montenegro, as the \% of the total unemployed

\begin{tabular}{|c|c|c|c|c|c|c|}
\hline Type & Measure & 2014 & 2015 & 2016 & 2017 & 2018 \\
\hline \multirow{4}{*}{ Upskilling (1) } & Education and qualification of adults & 4.47 & 2.44 & 0.91 & 1.07 & 3.13 \\
\hline & Qualification for work at the employer & 0.58 & 1.34 & 0.50 & 0.19 & 0 \\
\hline & $\begin{array}{l}\text { Professional rehabilitation of employable } \\
\text { persons }\end{array}$ & 0.86 & 0.41 & 0.42 & 0.35 & 0.75 \\
\hline & Total (1) & 5.92 & 4.20 & 1.84 & 1.63 & 3.88 \\
\hline \multirow{2}{*}{ Occupation (2) } & Public jobs & 2.53 & 3.46 & 2.21 & 2.36 & 3.25 \\
\hline & Total (2) & 2.53 & 3.45 & 2.21 & 2.36 & 3.25 \\
\hline \multirow{8}{*}{$\begin{array}{l}\text { Employment } \\
\text { assistance (3) }\end{array}$} & Qualification for individual work & 0 & 0.30 & 0.14 & 0.09 & 0 \\
\hline & $\begin{array}{l}\text { Informing of possibilities and conditions } \\
\text { for employment }\end{array}$ & 14.08 & 8.74 & 7.64 & 14.93 & 27.80 \\
\hline & Professional orientation & 37.88 & 25.63 & 19.05 & 26.23 & 36.59 \\
\hline & Mediation & 9.33 & 21.49 & 19.90 & 29.38 & 33.13 \\
\hline & Employment subventions & 0.97 & 0.77 & 0.50 & 0.65 & 1.59 \\
\hline & Support for self-employment & 0 & 0 & 0 & 0 & 0.02 \\
\hline & Scholarships & 0 & 0 & 0 & 0 & 0 \\
\hline & Total $^{*}(3)$ & 62.25 & 56.94 & 47.24 & 71.31 & 71.34 \\
\hline
\end{tabular}

* The total number does not include individual plans, as explained.

Source: Employment Agency of Montenegro, 2014, 2015, 2016, 2017, 2018.

has been significantly reduced, while employment assistance measures participation has increased. The 2018 saw an increase in the number of participants, but it was still far below the 2014 level.

There are several possible explanations for this. First, the Employment Agency of Montenegro does not provide enough incentives for individuals to participate in upskilling because it does not help them improve their career chances; second, information are not available, as well as the possible outcomes, so the participation rates are low; third, these programmes are not well developed and their implementation is not coordinated, resulting in an actual low investment outcome for participants. In other words, social investment is very poorly represented in the actual implementation of measures with the highest potential.
The expenditure includes measures from Table 4 and the apprentice programme, which is discussed later and which is not included here, due to its specific origin, nature and separate financing. Comparing budget share for ALMPs (Figure 1) also shows negative trends in Montenegro. Austerity measures have had a negative impact, especially after 2010, which was also confirmed in the Government's strategic documents (Ministry of Work and Social Welfare, 2015a). The same documents state that the sudden drop in funding ALMPs from 2010 was the result of the introduction of austerity measures, which refocused resources on direct financial help and support. The funds were moved to reparation and short-term measures, mostly in cash, which aimed at reducing risks for individuals and families (Ministry of Work and Social Welfare, 2015a; 2015b). Consequently, social investment, represented in ALMPs, almost disappeared from the agenda. 
Figure 1

ALMP Expenditure in Montenegro as the \% of the annual state budget

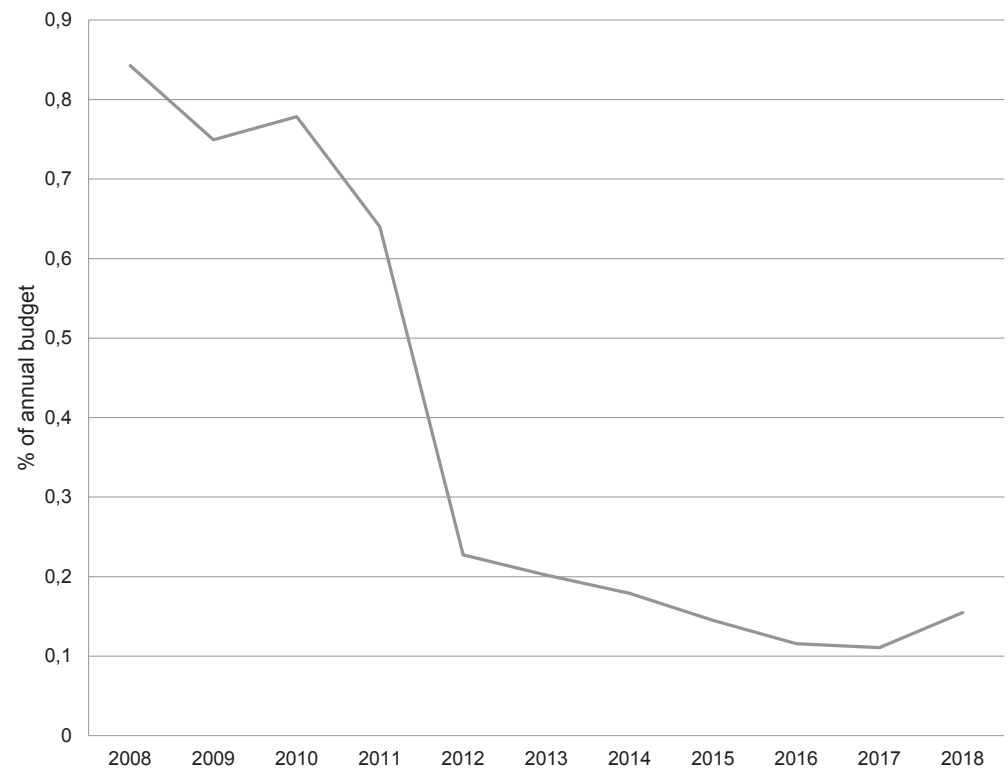

Source: Employment Agency of Montenegro, 2011 - 2018, Zakon o budžetu, 2008 - 2018.

In other words, activating policies were not in the focus of the Government, the budget was severely cut and priority was given to short-term measures. A modest increase to $0.15 \%$ in 2018 was not a significant change, but it made a positive effect on a number of participants. However, as already stated, it is still low.

\section{(Counter)Investment measures: the apprentice scheme on occupational development and mothers' allowances}

Women and youth are of special relevance due to their importance in the context of social investment in Montenegro. First, the number of faculty-educated women is growing in comparison to men (Bošković, 2013; 2018). Consequently, lower prospects for finding a job might further diminish women's and youth's economic wellbeing.
Second, there are two measures (laws) that will be mentioned here, which are closely related to social investment, the one for youth and the other for women. However, the two programmes implemented in Montenegro introduced contrary outcomes.

Youth unemployment rates in Montenegro are especially relevant here because of the special apprentice programme (scheme) on occupational development. It is not included in the previous discussion on ALMPs because it is regarded as a separate programme, regulated by the specific legal framework. Participants are not apprentices in the exact sense of the word because the scheme was introduced by the special law, so this term is used here as the most appropriate one. The programme was introduced in 2012 and it is mentioned not as a part of ALMPs per se, but as a policy with a high social investment prospect. It is defined as 
a continuous, programmatic and systemic activity for obtaining knowledge, skills and competences for accomplishing necessary work (Law on occupational development of persons with high education degree, 2012). It is organised as a 9-months internship for individuals with a faculty degree and no working experience. Companies and institutions advertise free positions and each person can have more than one choice and in the end decide whether or not to accept the position. The programme is funded by the government. The number of participants is presented in the Table 6 . them, but also for employers because it is funded by the state. It is an opportunity to obtain skills and apply knowledge gained at the university and prove one's abilities at the workplace. It should be a way of overcoming high youth unemployment rates by linking employers and young employees. Equally important, they are able to choose where to work, and are therefore able to work in the area of their education.

However, there are two major flaws that can be identified as discouraging. First, the law does not guarantee a placement after the end of the programme and employers

Table 5

The number of participants in the apprentice scheme per year

\begin{tabular}{|c|c|c|c|c|c|}
\hline Year & $\begin{array}{l}\text { Total number of } \\
\text { graduates }\end{array}$ & $\begin{array}{c}\text { Number of } \\
\text { participants in } \\
\text { total }\end{array}$ & $\begin{array}{l}\text { Participants } \\
\text { as \% of the } \\
\text { total number of } \\
\text { graduates }\end{array}$ & $\begin{array}{l}\text { Difference from } \\
\text { the previous year } \\
(\%)\end{array}$ & $\begin{array}{c}\% \text { of the } \\
\text { annual budget } \\
\text { expenditure }\end{array}$ \\
\hline 2012 & 4515 & 4211 & 93.26 & I & I \\
\hline 2013 & 4711 & 3945 & 83.74 & -6.10 & 0.726 \\
\hline 2014 & 4376 & 3597 & 82.20 & -9.03 & 0.596 \\
\hline 2015 & 4321 & 3458 & 80.02 & -3.86 & 0.432 \\
\hline 2016 & 4825 & 3319 & 68.79 & -4.02 & 0.418 \\
\hline 2017 & 4860 & 3360 & 69.13 & +1.24 & 0.398 \\
\hline 2018 & 4768 & 3055 & 64.07 & -9.08 & 0.399 \\
\hline
\end{tabular}

* Due to specific nature of the educational system in Montenegro, the number includes graduates with a Bachelor degree (3 years studies) and a Specialist degree (4 years of education), because the programme aims at participants from both categories.

Source: Employment Agency of Montenegro, 2013 - 2018, Zavod za statistiku, 2019.

The table shows dropping numbers of participants in the programme and points to its rather unpromising future. Together with the lowering budget, it cannot be expected to have a positive impact as it has the potential to. In the sense of social investment, this policy should be an excellent example of the approach because it provides young and educated people with a job opportunity immediately after finishing university. Therefore, it should be encouraging for decide if the employee will be offered a contract. Second, it is organised as a way of providing short-term low paid work, because the user earns $50 \%$ of average net wage in the country, which means around 250 euros per month. This amount is very low for the Montenegrin standard of living and provides no incentive for programme users beside the opportunity to have a job. These two are here seen as the two highly discouraging factors for participation in the programme, which re- 
sulted in lowering the number of participants. On the other hand, there is another possibility which might have a negative impact on wages. Namely, employers may reduce wages to persons who begin to work with them for the first time because they can employ a person from the programme so there is no incentive to provide higher wages. There has been no research on this, but it is an assumption that is already being discussed.

The second measure of relevance here are so-called "mothers' allowances". It was effective from January 2017 to February 2018. This policy enabled women with three or more children, and 15 or 25 years of work experience to accept a life-time allowance, at a rate of 70 or 40 per cent of the average monthly wage in Montenegro respectively, depending on the length of previous work (Law on the amendments of the law on social and child care, 2015). A considerable number of unemployed women (around 6,000) accepted the allowance, out of 22,051 women who accepted the allow- ance in total (Ustavni sud Crne Gore, 2017). However, as the allowance was annulled by the Constitutional Court, the number of long-term unemployed women increased sharply for 6 per cent in 2017 (Employment Agency of Montenegro, 2018).

It can be assumed to be the result of some of the women returning to the labour market and to the unemployed status they had had prior to the allowance. The number of long-term unemployed men decreased (Employment Agency of Montenegro, 2018) and it is the reason why there was no significant change in 2017 for the total number of the long-term unemployed. A significant increase of long-term unemployed in 2018 may be ascribed to the same policy, as the result of slow recording of a high number of women's requests for refusal of the allowance. Consequently, it is only after a while that the negative impact of the policy becomes fully visible. The Figure 2 shows a rather negative picture for Montenegro, in comparison to the EU.

Figure 2

Long-term unemployment 15-64, 2008 to 2016.

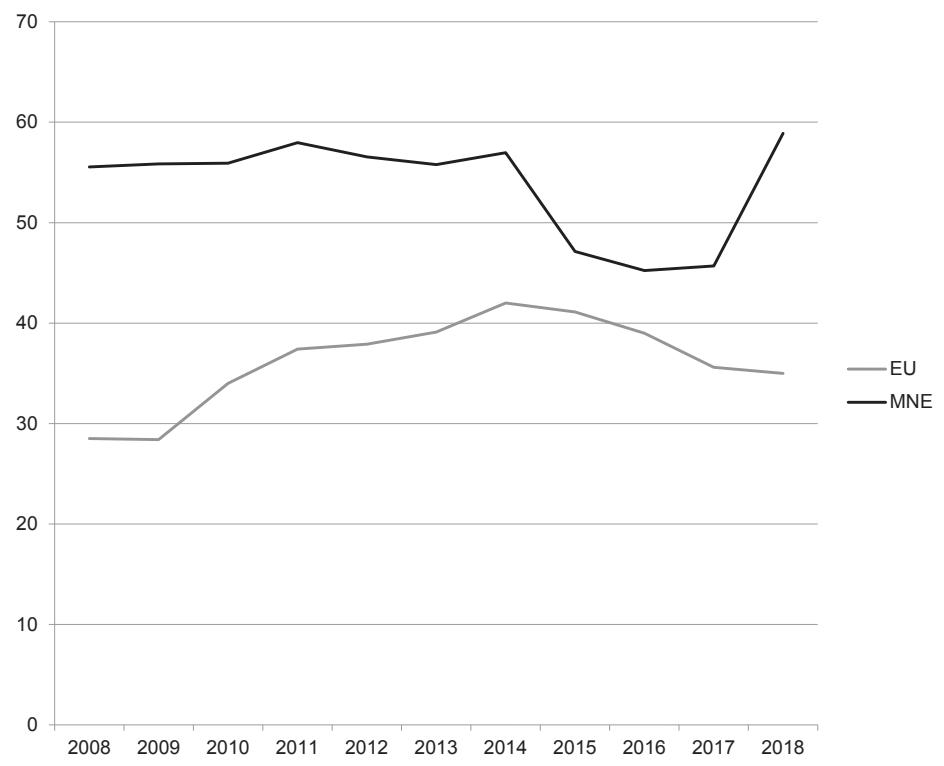

Source: Eurostat, 2018; Employment Agency of Montenegro, 2009 - 2018. 
Ministry of Work and Social Welfare does not have the exact data on how many women returned to work or to unemployment (Ministry of Work and Social Welfare, 2018) so the final negative assessment of the measure is not possible. No official report has been published on it yet, further revealing its speculative character and entirely political background, as it was adopted in the electoral year. However, in relationship to social investment, its negative impact was tremendous.

This policy had counter-investment character. The original aim was to increase fertility rates by allowing women to stay at home, but this approach has negative effects in manifold ways: economically, politically, and culturally. But crucially, taking beneficiaries out of the labour market and effectively lowering participation rates for women meant their further downgrading in the long run. On the other hand, the law was discriminatory and selective. It was a measure that put an even larger strain on the state budget and was annulled, but no systemic effort to help women who had to give up this opportunity has been recorded, which is another counter-investment move. Lowering budget for ALMPs, as presented before, could only increase their risk of poverty and social exclusion, having no funds devoted for helping these women return to work more effectively.

\section{DISCUSSION: FOCUS IS AWAY FROM HUMAN CAPITAL}

A continuous growth of unemployment in Montenegro since 2008 was not followed by an increase in the active labour market policies funds, but exactly the opposite. A positive turn in 2018 still needs to be assessed in the forthcoming period. Increasing employment rates should be followed by lowering interest for ALMPs, but rising unemployment implies a need to offer alternative ways to either new employment or protection of skills and human capital. Martin (2015) proves this for OECD countries in his study against critics of this approach. Long-term unemployment spells make it even more difficult to get a job as it is an additional risk for an employer (Bonoli, 2009). However, severe budget decreases made it even more difficult for the measures to make effect and have a positive impact on employment rates.

What is missing is a more personal approach, which would be more helpful, as social investment specifically aims at personalisation and contextualisation of specific measures. In other words, there should be more transparency of the data and evaluation of prospective behaviour of the interviewed individuals. Evaluation of their employment status would improve possibilities offered by these policy measures and enable inclusion into the official statistics on ALMPs.

The Employment Agency of Montenegro has to further develop ways of delivering specific skills individuals have, to prospective employers that might need them. There should be better ways of connecting employers and employees and ALMPs are especially relevant here because they increase individuals' capacities. However, these are not presented adequately and those who participate in different programmes often find it difficult to enter a new job. The Agency should further develop ways for ALMP participants to find jobs.

Looking at the hypothesis of the paper, it is not confirmed. It means that social investment is present in the employment policies in the sense of existing legal norms, but in practice, it is not functional. The number of participants in ALMPs confirms this as well as two policies: apprentice programme, which does realise its investment potential and mothers' allowances with a high counter-investment character. Lowering budget share devoted to ALMPs is a further proof 
that social investment is not high on the agenda of the Montenegrin government.

Comparing current employment trends reveals severe legging behind the European Union numbers and national strategic documents goals, which are already significantly below the Europe 2020 agenda, and which have not been met. European dimension can be applied to active labour market policies. On the one hand, it is a positive outreach to see a developed set of policy measures in the Montenegrin legal framework. A clearer delineation between the specific measures' aims and ways they can be taken by the unemployed and how to assess their effectiveness is missing. As already mentioned, defining all of the ALMP as measures aimed at reducing unemployment is unattainable. It is only some of the measures that have this effect.

The effects of mothers' allowances are negative as well. There was a lowering of women's unemployment rate in 2016 and a drop in the long-term unemployed (almost 10 per cent). But in 2018, more than a year after the policy was annulled, the number of long-term unemployed soared, especially for women. Dropping rates for employment and unemployment in 2018 are a positive sign, but it already pointed to possible negative implications in the long run, especially for women. The weak regulatory framework of the mothers' allowances allowed ample space for manipulations. Furthermore, informal work would have been difficult to control, making the essential sense of the policy measure disappear. In conclusion, further similar policies should be preceded by more refined analyses and solid legal framework. Social investment approach with stronger services should be the leading perspective, as fiscal consolidation measures are still in place.

Fiscal consolidation measures have had a similarly negative effect on the expansion of social investment. Consequently, it is hard to expect an increase in social care spending now, but most likely in the following few years as well. It also implies that social investment will remain underfunded and undeveloped. Active labour market policies should be promoted to a wider audience and one of the solutions is to set stricter criteria for eligibility for the unemployment benefits. The Danish case may be a blue-print, but there should be further studies before it is enacted, due to a heavy segmentation of the labour market in Montenegro. As already mentioned, eligibility criteria in Montenegro are not among the strictest, compared to some of the EU member states, however the very nature of benefits is not supportive for finding satisfying jobs but rather accepting any opportunity.

ALMPs should have a more prominent place, as well as other types of education that can improve individuals' skills. Matching skills with offered positions is essential and ALMPs can be an effective way to gain an employment, having positive outcomes both for the individual and the state budget. Studies looking at behaviour of the unemployed should be undertaken, so the visibility and popularity of various ALMPs can be assessed, together with activating measures.

The apprentice programme in Montenegro could be a good policy option to boost employment and improve the chances of young people with a faculty degree to find a proper job. Knowing how many individuals were kept in the job or at least in the same company or institutions would be a major criterion. However, positions are not always offered according to the real needs of the employer and the apprentices lack the actual tasks they are assigned to. Consequently, their skills are not developed or are even depleted, due to performing tasks of lower requirements. On the other hand, employers are not obliged to keep apprentices and it is occasionally the case that they use the program to employ free work force 
for 9 months. Instead of being a good example of social investment policy, it often has quite the opposite effect.

One of the options could be that employers pay a portion of the salary to the intern or have an obligation to keep them at work at least for some time after the programme officially ends. It would have the effect on an employer to be more responsible in offering places and prospective workers could feel safer and more dedicated to the job, which is not the case with the current programme. Additionally, there is a need for establishing an appropriate regulatory framework, ensuring quality of the programme together with qualifications, competences and standards, high-quality learning, career guidance for young people with fewer opportunities together with preparatory trainings. These are the major recommendations from the European quality framework for apprenticeships (ETUC, 2018). There is currently none which regulates the apprentice programme in Montenegro. Introducing these recommendations would further strengthen social investment approach for the young.

All of this means that human capital is not a top priority in practice. The Montenegrin government is focused on providing basic social security measured through protection, rather than enabling, which is therefore creating further budget pressure in the long run.

\section{CONCLUSION}

The Montenegrin case of social policy reforms shows that a solid legal framework and optimistic strategic thinking were not enough for the labour market in Montenegro to show similar outcomes to the European Union member states. Despite the fact that it may prove to be difficult in practice, as it has been presented in this paper, Montenegro performs similarly or even worse than the lowest ranking member states on all of the indicators.
Social investment is present in a categorisation of active labour market policies, but their implementation is curtailed by budget decreases and low participation rates. ALMPs have ample normative space to be implemented in the Montenegrin context, but missing specific policy aims and their detailed implementation strategies reduce reaching desired outcomes. Social investment needs careful development and even more carefully designed implementation but both are missing in the Montenegrin case.

Women and young persons appear to be in the worst situation, due to their already vulnerable social position. Some policies mentioned in this paper, mothers' allowances as the counter-investment measure and the apprentice scheme with its high investment potential did not have a positive outreach. Therefore, social investment needs further and detailed elaboration in Montenegrin official documents in order to prevent cases of drastically reversing policy measures. But more importantly, this is needed so that the potential of policy measures can be realised if it is present. Active labour market policies have this potential.

Unofficial discussions mention the year of 2025 as the accession year for Montenegro and the following period is long enough for introducing changes in the labour market policies. If that is not the case, Montenegrin citizens will face severe competition and risks in the labour market and it is especially the case with women and young people. Social investment is an approach that aims at reducing these risks and this paper has shown the need of its inclusion in planning and implementing of labour market policies in Montenegro.

\section{REFERENCES}

Bonoli, G. (2007). Time matters: Postindustrialization, new social risks, and welfare state adaptation in advanced industrial democracies. Com- 
parative Political Studies, 40(5), 495-520.https:// doi.org/10.1177/0010414005285755

Bonoli, G. (2009). Varieties of social investment in labour market policy. In N. Morel, B. Palier \& J. Palme (Eds.), What Future for Social Investment? (pp. 55-66). Stockholm: Institute for futures studies.

Bonoli, G. (2012). Active labour market policy and social investment: A changing relationship. In N. Morel, B. Palier \& J. Palme (Eds.), Towards a Social Investment Welfare State? (pp. 181-204). Bristol: Bristol University Press.

Bošković, B. (2013). Žene i obrazovanje: Evropska perspektiva Crne Gore. U Obrazovanje i razvoj (str. 328-336). Beograd: Institut društvenih nauka, Centar za ekonomska istraživanja.

Bošković, B. (2015). Država socijalnog investiranja: mogućnosti stvaranja nove Evrope?. U I. Vujačić \& N. Beljinac (ur.), Nova Evropa i njena periferija (pp. 309-322). Beograd: Fakultet političkih nauka, Udruženje za političke nauke Srbije.

Bošković, B. (2018). Obrazovanje u Crnoj Gori: važnost, trendovi i efekti. U Sociološki presjek crnogorskog društva (str. 489-508). Podgorica: Crnogorska akademija nauka i umjetnosti.

Bouget, D., Frazer, H., Marlier, E., Sabato, S., \& Vanhercke, B. (2015). Social investment in Europe: A study of national policies. European Social Policy Network (ESPN). Brussels: European Commission.

Caliendo, M., \& Schmidl, R. (2016). Youth unemployment and active labor market policies in Europe. IZA Journal of Labor Policy, 5, 1-30.

Clasen, J., \& Clegg, D. (2006). Beyond activation: Reforming European unemployment protection systems in post-industrial labour markets. European Societies, 8(4), 527-553. https://doi. org/10.1080/14616690601002582

Employment Agency of Montenegro. (2012). Work report for 2011. Podgorica: Employment Agency of Montenegro.

Employment Agency of Montenegro. (2013). Work report for 2012. Podgorica: Employment Agency of Montenegro.

Employment Agency of Montenegro. (2014). Work report for 2013. Podgorica: Employment Agency of Montenegro.

Employment Agency of Montenegro. (2015). Work report for 2014. Podgorica: Employment Agency of Montenegro.

Employment Agency of Montenegro. (2016). Work report for 2015. Podgorica: Employment Agency of Montenegro.
Employment Agency of Montenegro. (2017). Work report for 2016. Podgorica: Employment Agency of Montenegro.

Employment Agency of Montenegro. (2018). Work report for 2017. Podgorica: Employment Agency of Montenegro.

Esping Andersen, G., Gallie, D., Hemerijck, A., \& Myles, J. (2002). Why we need a new welfare state. Oxford: Oxford University Press.

Esser, I., Ferrarini, T., Nelson, K., Palme, J., \& Sjoberg, O. (2013). Unemployment benefits in EU member states. Brussels: European Commission.

European Commission. (2006). Labour market policy database: Methodology. Directorate F - Unit F/2 Labour Market Statistics.

European Commission. (2010a). An Agenda for new skills and jobs. COM(2010) 682 final.

European Commission. (2010b). Europe 2020. A strategy for smart, sustainable and inclusive growth. COM(2010) 2020. https://eur-lex.europa.eu/legal-content/en/ALL/?uri=CELEX\%3A52010DC2020

European Commission. (2013a). Towards Social Investment for Growth and Cohesion - including implementing the European Social Fund 20142020. COM(2013) 83 final.

European Commission. (2013b). Investing in children: breaking the cycle of disadvantage. COM(2013) 778 final.

European Commission. (2016). Montenegro 2016 Report. COM(2016). 715 final.

European Commission. (2017). European Pillar of Social Rights. Brussels: European Commission. Available at https://ec.europa.eu/commission/ sites/beta-political/files/social-summit-european-pillar-social-rights-booklet_en.pdf

European Commission. (2018). Montenegro 2018 Report. COM(2016). 450 final.

European Trade Union Confederation. (2018). A European Quality Framework for Apprenticeships: A European Trade Union Proposal. Brussels: ETUC.

Eurostat. (2018). Labour force survey database. Brussels: Eurostat.

Hemerijck, A. (2013). Changing welfare states. Oxford: Oxford University Press.

Hemerijck, A. (2014). Making social investment happen for the eurozone. Intereconomics, (51), 341347. https://doi.org/10.1007/s10272-016-0632-9

Hemerijck, A. (2015). The quiet paradigm revolution of social investment. Social Politics, 22(2), 242256. https://doi.org/10.1093/sp/jxv009 
Hemerijck, A. (2017). Social investment and its critics. In A. Hemerijck (Ed.), The Uses of Social Investment (pp. 3-39). Oxford: Oxford University Press.

Hemerijck, A., \& Vandenbroucke, F. (2012). The welfare state after the great recession. Intereconomics, (47), 200-229. https://doi.org/10.1007/ s10272-012-0422-y

Jenson, J., \& Saint-Martin, D. (2006). Building blocks for a new social architecture: The LEGO paradigm of an active society. Policy \& Politics, 34(3), 429-451. https://doi. org/10.1332/030557306777695325

Jenson, J. (2009). Redesigning citizenship regimes after neoliberalism: Moving towards social investment. In N. Morel, B. Palier \& J. Palme (Eds.), What Future for Social Investment? (pp. 27-44). Stockholm: Institute for Futures Studies.

Jenson, J. (2012). Redesigning citizenship regimes after neoliberalism: Moving towards social investment. In N. Morel, B. Palier \& J. Palme (Eds.), Towards a Social Investment Welfare State? (pp. 61-87). Bristol: Bristol University Press.

Katnić, M. (2017). Minimalna zarada u Crnoj Gori. Podgorica: UNDP.

Martin, J. P. (2014). Activation and active labour market policies in OECD Countries: stylised facts and evidence on their effectiveness. IZA Journal of Labor Policy, 84. Available at http:// ftp.iza.org/pp84.pdf

Margquet, I., Masetri, V., \& Thevenot, C. (2016). The coverage rate of income support measures in the EU: Measurement and challenges. Brussels: European Commission.

Ministry of Work and Social Welfare. (2015a). Poglavlje 19 - Socijalna politika i zapošljavanje. Akcioni plan. Podgorica: The Government of Montenegro.

Ministry of Work and Social Welfare. (2015b). Nacionalna strategija zapošljavanja i razvoja ljudskih resursa 2016-2020. Tržište rada na evropskom putu. Podgorica: The Government of Montenegro.

Ministry of Work and Social Welfare. (2015c). Program reforme politike zapošljavanja i socijalne politke 2015-2020, predlog. Podgorica: The Government of Montenegro.
Ministry of Work and Social Welfare. (2018). Decision no. 007-93/18-2. Podgorica: Ministry of Work and Social Welfare.

Zavod za statistiku. (2014). Procjena stanovništva Crne Gore do 2060. godine. Podgorica: Zavod za statistiku.

Zavod za statistiku. (2019). Visoko obrazovanje - Saopštenja. Dostupno na https://www.monstat.org/ $\mathrm{cg} /$ page.php? $\mathrm{id}=437 \&$ pageid $=76$

Morel, N., Palier, B., \& Palme, J. (2012). Beyond the welfare state as we knew it?. In N. Morel, B. Palier \& J. Palme (Eds.), What Future for Social Investment? (pp. 1-30). Stockholm: Institute for futures studies.

Nolan, B. (2013). What use is 'social investment'?. Journal of European Social Policy, 23(5), 459468. https://doi.org/10.1177/0958928713499177

Organisation for Economic Co-operation and Development. (2013). OECD Employment outlook 2013. Paris: OECD Publishing.

Pierson, P. (2011). The welfare state over the very long run. ZeS-Arbeitspapier, No. 02/2011.

Polanyi, K. (2006). Velika transformacija. Beograd: Filip Višnjić.

Ustavni sud Crne Gore. (2017). Odluka o ukidanju odredaba člana 4. Zakona o dopunama i izmjenama Zakona o socijalnoj i dječijoj zaštiti (Službeni list Crne Gore, broj 42/15.).

Venn, D. (2012). Eligibility criteria for unemployment benefits: Quantitative indicators for OECD and EU countries. OECD Social, Employment and Migration Working Papers, No. 131. Paris: OECD Publishing.

Vandenbroucke, F., Hemerijck, A., \& Palier, B. (2011). The EU needs a social investment pact. OSE Paper Series, Opinion paper No.5.

Zakon o budžetu Crne Gore. Official Gazette of Montenegro, 2009, 2010, 2011, 2012, 2013, 2014, 2015, 2016, 2017, 2018.

Zakon o dopunama zakona o socijalnoj i dječijoj zaštiti. Official Gazette of Montenegro, 42/2015.

Zakon o stručnom osposobljavanju lica sa stečenim visokim obrazovanjem. Official Gazette of Montenegro, 38/2012.

Zakon o zapošljavanju i ispunjavanju prava iz osiguranja od nezaposlenosti. Official Gazette of Montenegro, 52/2016. 
Sažetak

\title{
MJERE TRŽIŠTA RADA I SOCIJALNO ULAGANJE U CRNOJ GORI: DOSTIZANJE EUROPSKIH STANDARDA I PRAKSE?
}

\author{
Branko Bošković \\ Humanističke studije, Univerzitet Donja Gorica \\ Donja Gorica, Podgorica, Crna Gora
}

U radu se analiziraju mjere tržišta rada u Crnoj Gori iz perspective socijalnog ulaganja. Crna Gora je zemlja kandidat za članstvo u Europskoj uniji i postoji potreba za usklađivanjem normativnog okvira. Socijalno ulaganje zadobiva znatnu pozornost kreatora politika u Europskoj uniji i nalazi se visoko na listi prioriteta socijalne politike. Slijedom toga, u radu se analizira funkcionira li crnogorsko tržište rada na sličan način kao ona u Europskoj uniji. Cilj rada je pokazati hoće li crnogorsko tržište rada biti spremno za pristupanje Europskoj uniji, kako normativno tako i u praksi. Analiza je usmjerena na aktivne politike tržišta rada jer su one jedna od najreprezentativnijih mjera socijalnog ulaganja u ovom području. Posebno se analiziraju dvije specifične mjere: takozvane naknade za majke i pripravnički program. Analiza pokazuje da Crna Gora ima dobru polazišnu točku u pogledu zakonskog okvira, ali u praksi nema socijalnog ulaganja.

Ključne riječi: Crna Gora, Europska unija, socijalna politika, aktivne politike tržišta rada, socijalno ulaganje. 